William \& Mary Law School

William \& Mary Law School Scholarship Repository

7-2015

\title{
Three Grotian Theories of Humanitarian Intervention
}

Evan J. Criddle

William \& Mary Law School, ejcriddle@wm.edu

Follow this and additional works at: https://scholarship.law.wm.edu/facpubs

Part of the Human Rights Law Commons, and the International Law Commons

\section{Repository Citation}

Criddle, Evan J., "Three Grotian Theories of Humanitarian Intervention" (2015). Faculty Publications. 1785. https://scholarship.law.wm.edu/facpubs/1785

Copyright c 2015 by the authors. This article is brought to you by the William \& Mary Law School Scholarship Repository.

https://scholarship.law.wm.edu/facpubs 


\title{
Three Grotian Theories of Humanitarian Intervention
}

\begin{abstract}
Evan J. Criddle*
This Article explores three theories of humanitarian intervention that appear in, or are inspired by, the writings of Hugo Grotius. One theory asserts that natural law authorizes all states to punish violations of the law of nations, irrespective of where or against whom the violations occur, to preserve the integrity of international law. A second theory, which also appears in Grotius's writings, proposes that states may intervene as temporary legal guardians for peoples who have suffered intolerable cruelties at the hands of their own state. Each of these theories has fallen out of fashion today based on skepticism about their natural law underpinnings and concerns about how they have facilitated Western colonialism. As an alternative, this Article outlines a third theory that builds upon Grotius's account of humanitarian intervention as a fiduciary relationship, while updating Grotius's account for the twenty-first century. According to this new fiduciary theory, when states intervene to protect human rights abroad they exercise an oppressed people's right of self-defense on their behalf and may use force solely for the people's benefit. As fiduciaries, intervening states bear obligations to consult with and honor the preferences of the people they seek to protect, and they must respect international human rights governing the use of force within the affected state. By clarifying the respective responsibilities of the Security Council and individual states for humanitarian intervention, the fiduciary theory also lends greater coherency to the international community's "responsibility to protect" human rights.
\end{abstract}

* Professor of Law and Tazewell Taylor Research Professor, William \& Mary Law School. 


\section{INTRODUCTION}

This Article examines three theories of humanitarian intervention ${ }^{1}$ that can be traced to Hugo Grotius, the brilliant seventeenth-century Dutch scholar and diplomat whose writings have left an indelible mark on international law. Two of the theories appear in Grotius's influential treatise On the Laws of War and Peace. ${ }^{2}$ The third theory, while not advanced by Grotius himself, seeks to reconcile Grotius's ideas with a key feature of the contemporary international legal order: the U.N. Security Council's exclusive authority under the U.N. Charter to authorize humanitarian intervention. ${ }^{3}$ All of these theories qualify as "juridical theories" insofar as they seek to explain the formal legal basis, structure, and scope of state authority to use force in response to human rights violations abroad. Despite their common tie to Grotius, however, the three theories offer distinct visions of the purpose and limits of humanitarian intervention.

The first theory asserts that when states use force in response to human rights violations abroad, the primary purpose is to punish the violation of international norms in order to protect the integrity of international law as a normative order. Grotius famously argued that all states are entitled to punish violations of the law of nature (ius naturale) and the positive law of nations (ius gentium), ${ }^{4}$ irrespective of where or against whom the violations occur, to vindicate the rule of law. ${ }^{5}$ Echoes of this theory can be discerned in contemporary practice, as some states continue to argue that they may use force without the U.N. Security Council's authorization to counter serious violations of international law. Yet, the idea that international law supports a universal right of punishment no longer commands widespread acceptance

1 Although the term "humanitarian intervention" may refer to other measures such as economic coercion and the delivery of humanitarian aid, this Article focuses on the narrower question whether states may use force to protect human rights abroad.

2 Hugo Grotius, On the Law of War and Peace (A.C. Campbell trans., London 1814) (1625).

3 U.N. Charter art. 42.

4 For Grotius, "natural law" denotes rules derived from "right reason, shewing the moral turpitude, or moral necessity, of any act from its agreement or disagreement with a rational nature." Grotius, supra note 2, bk. I, ch. 1, pt. X. In contrast, the "law of nations" represents a system of positive rights applicable to the relations among sovereign states, and between sovereign states and their people, "deriving its authority from the consent of all, or at least of many nations.” Id. bk. I, ch. 1, pt. XIV.

$5 \quad$ Id. bk. II, ch. 20, pt. VII. 
across the international community. Most international lawyers now reject the idea that states are entitled to punish one another unilaterally, based on concerns that a state's unilateral assertion of punitive powers over another state presupposes a hierarchical relationship that is inconsistent with the principle of sovereign equality. ${ }^{6}$ Moreover, the suggestion that humanitarian intervention is fundamentally punitive in nature does not mesh well with the primarily defensive character of humanitarian intervention as observed in practice. Grotius's general theory of international law enforcement is illsuited, therefore, to explain when and how states may engage in humanitarian intervention today.

A second theory of humanitarian intervention appears in a passage from $\mathrm{On}$ the Law of War and Peace that has passed into relative obscurity. Addressing his attention to the "Causes of Undertaking War for Others," Grotius asserts that the law of nature authorizes states to serve as temporary guardians for foreign nationals abroad who have suffered intolerable cruelties at the hands of their own state. ${ }^{7}$ Under Grotius's guardianship theory, states that use force to protect human rights abroad exercise a foreign people's natural right to resist oppression on their behalf, and they accordingly bear fiduciary obligations to use force solely for the benefit of a foreign people. Unlike Grotius's theory of international punishment, this guardianship theory resonates with the contemporary practice of humanitarian intervention in important respects; states that invoke humanitarianism as a basis for intervention tend to justify their actions as a purely defensive measure undertaken for and on behalf of an oppressed people to prevent death and suffering. ${ }^{8}$ On the other hand, Grotius's guardianship theory is vulnerable to the objection that the international community has retreated from the idea that natural law constitutes an independent source of authority for military intervention. ${ }^{9}$ Moreover,

6 See Harry D. Gould, The Legacy of Punishment in International Law 29-34 (Palgrave Macmillan 2010); Alexis Blane \& Benedict Kingsbury, Punishment and the Ius Post Bellum, in The Roman Foundations of the Law of Nations: Alberico Gentili and the Justice of Empire 241, 241-43 (Benedict Kingsbury \& Benjamin Straumann eds., 2010) (observing that states no longer formally justify inter-state enforcement measures in punitive terms).

7 Grotius, supra note 2, bk. II, ch. 25, pt. VIII.

8 See, e.g., Press Statement of NATO Secretary-General Javier Solana, NATO Press Release 040 (Mar. 23, 1999) (explaining that NATO intervention in Kosovo would "be directed towards disrupting . . . violent attacks" and "prevent[ing] more human suffering and more repression and violence").

9 See John J. Merriam, Note, Kosovo and the Law of Nations, 33 CASE W. Res. L. Rev. 111, 118 (2001); cf. Hersch Lauterpacht, The Grotian Tradition in International Law, 23 BRIT. Y.B. INT'L L. 1, 46 (1946) ("The doctrine of 
fiduciary concepts such as "guardianship" and "trusteeship" have a disturbing historical legacy, as colonial powers have used these concepts to dress up their domination and exploitation of first nations as a form of benevolent humanitarianism. ${ }^{10}$ The fact that Grotius's guardianship theory allows each state to judge for itself the legality of its intervention further augments its potential for abuse. As a result, Grotius's vision of humanitarian intervention as a guardian-ward relationship between intervening states and oppressed foreign peoples has all but disappeared from contemporary legal discourse.

As an alternative to Grotius's own theories, this Article articulates and defends a third theory of humanitarian intervention that draws inspiration from Grotius's guardianship theory. Although Grotius could not have anticipated the U.N. Charter's collective security regime, the juridical structure of humanitarian intervention as authorized by the U.N. Security Council bears the hallmarks of a fiduciary relationship akin to guardianship or trusteeship. When the Security Council green-lights humanitarian intervention, it entrusts states and regional organizations with authority to use force abroad in a fiduciary capacity. Like other fiduciaries in private and public law, states that engage in humanitarian intervention hold discretionary power over the legal and practical interests of their designated beneficiaries (foreign nationals), and they bear a concomitant fiduciary obligation to exercise this power exclusively for their beneficiaries' benefit. These features of the juridical structure of humanitarian intervention clarify the legal basis and scope of states' authority to protect human rights abroad. For ease of reference, I refer to this account — which takes inspiration from Grotius, but does not depend on Grotius's own natural law premises as the "fiduciary theory" of humanitarian intervention.

The remainder of this Article introduces the fiduciary theory in four steps. Part I reviews Grotius's theory that states have a universal right to punish violations of the law of nature, and it explains why this theory does not offer a plausible theoretical framework for humanitarian intervention today. Part II describes Grotius's lesser-known guardianship theory of humanitarian intervention and evaluates its strengths and weaknesses. Drawing insights from Grotius's guardianship theory, Part III outlines the fiduciary theory of humanitarian intervention and shows how the theory fits within the landscape of contemporary international norms and institutions, including the controversial

humanitarian intervention has never become a fully acknowledged part of positive international law.").

10 See Antony Anghie, Imperialism, Sovereignty and the Making of International Law 28-30 (2005); Evan J. Criddle, A Sacred Trust of Civilization: Fiduciary Foundations of International Law, in Philosophical Foundations of Fiduciary LAw 404, 406-08 (Andrew Gold \& Paul Miller eds., 2014). 
Responsibility to Protect (R2P) principle. ${ }^{11}$ To illustrate how the fiduciary theory should inform the law and practice of humanitarian intervention prospectively, Part IV briefly sketches three proposals for reforming current international norms and institutions. First, when states engage in humanitarian intervention, the fiduciary theory suggests that they bear a corresponding obligation to consult with and honor the preferences of those whom they seek to protect. Second, intervening states must respect international human rights norms governing the use of force - including the strict proportionality standards associated with the human "right to life." 12 Third, when issuing resolutions that authorize humanitarian intervention, the Security Council should incorporate more robust procedural and substantive checks to ensure that intervening states can be held accountable for abusing their entrusted authority. For the fiduciary theory to transcend its colonialist past and serve as a credible bulwark against great-power domination, ${ }^{13}$ these and other concrete legal and institutional reforms will be necessary to ground the rhetoric of fiduciary duty in reality.

\section{Grotius's Theory of International Punishment}

The idea that states may enforce international law through punitive military action can be traced back to Grotius, who famously claimed that all members of international society were entitled to punish violations of natural law and the positive law of nations, irrespective of where or against whom the violations occurred. This universal license to punish was justified, Grotius argued, based on the absence of a "superior" authority in international society and the need for retribution and deterrence to vindicate principles of natural justice. ${ }^{14} \mathrm{~A}$ state did not need to demonstrate that it had suffered any individualized injury

11 See 2005 World Summit Outcome, G.A. Res. 60/1, ๆף 138-139, U.N. Doc. A/RES/60/1 (Sept. 16, 2005) [hereinafter World Summit Outcome].

12 International Covenant on Civil and Political Rights art. 6.1, opened for signature Dec. 19, 1966, 999 U.N.T.S. 171 (entered into force Mar. 23, 1976) [hereinafter ICCPR].

13 Some scholars argue that colonialism is a fundamentally unreformable feature of international law generally, and of humanitarian intervention in particular. See, e.g., China Miéville, Between Equal Rights: A Marxist Theory of International Law 3 (2005); Anne Orford, Reading Humanitarian Intervention: Human Rights AND the Use of Force in International Law 46-48 (2003).

14 See Grotius, supra note 2, bk. II, ch. 20, pt. III; Benjamin Straumann, The Right to Punish as a Just Cause of War in Hugo Grotius'Natural Law, 2 Stud. Hist. Eтнісs 1 (2006). 
before it could undertake enforcement action; instead, "any one of sound judgment who is not subject to vices of the same kind or of equal seriousness" could administer punishment. ${ }^{15}$ The mere fact that the law had been violated was sufficient cause to support enforcement action by any member of the international community.

Grotius stressed that his theory of punishment justified warfare for the purpose of punishing states that violate the law of nature. ${ }^{16}$ Hence, a sovereign could justly wage war "against those who feed on human flesh .... Regarding such barbarians, wild beasts rather than men, one may rightly say . . . that war against them is sanctioned by nature." ${ }^{17}$ According to Grotius's account, any state could rightfully claim authority to use force to punish another state's inhumane treatment of its own people because enforcement action was necessary to vindicate natural law.

Grotius's theory of international punishment continues to surface from time to time in international legal discourse today. A striking recent example is the reaction of the United States and the United Kingdom to Syria's use of chemical weapons against its own people during its ongoing civil war. In August 2013, the international news media reported that the Syrian government of Bashar al Assad had used poison gas during an assault against Adra, a densely inhabited northern suburb of Damascus ${ }^{18}$ The attack claimed nearly 1500 lives, including at least 426 children. ${ }^{19}$ Although Syria was not a party to the Chemical Weapons Convention at the time, ${ }^{20}$ its indiscriminate use of

15 Grotius, supra note 2, bk. II, ch. 20, pt. VII. John Locke famously echoed Grotius's theory of a universal right to punish. See John Locke, Second Treatise on Government $§ 7$ (C.B. Macpherson ed., 1980) (1690).

16 See Grotius, supra note 2, bk. II, ch. 20, pt. XL (arguing that sovereigns "have the right of demanding punishments not only on account of injuries committed against them or their subjects, but also on account of injuries which do not directly affect them but excessively violate the law of nature or of nations to any persons whatsoever").

17 Id.

18 Joby Warrick, More Than 1400 Killed in Syrian Chemical Weapons Attack, U.S. Says, WASH. Post, Aug. 30, 2013, http://www.washingtonpost.com/world/ national-security/nearly-1500-killed-in-syrian-chemical-weapons-attack-ussays/2013/08/30/b2864662-1196-11e3-85b6-d27422650fd5_story.html.

19 Id.

20 See Convention on the Prohibition of the Development, Production, Stockpiling and Use of Chemical Weapons and on Their Destruction, opened for signature Jan. 13, 1993, 1974 U.N.T.S. 316 (entered into force Apr. 29, 1997). Syria was a party to the Geneva Protocol for the Prohibition of the Use of Asphyxiating, Poisonous or Other Gases, and of Bacteriological Methods of Warfare at the 
chemical weapons against civilian neighborhoods violated bedrock principles of international humanitarian law that are widely accepted as universally binding in non-international armed conflict. ${ }^{21}$ The Adra attack also made headlines internationally because it crossed a "red line" that U.S. President Barack Obama had imposed against Syria exactly one year earlier, raising the possibility of an international military response. ${ }^{22}$

Both the United States and the United Kingdom swiftly declared that Syria's use of chemical weapons could not go unpunished. With the U.N. Security Council paralyzed by the threat of a Russian veto, U.S. President Barack Obama stated that he was prepared "to order a limited strike against the Assad regime ... to deter the further use of chemical weapons." ${ }^{.23}$ U.K. Prime Minister David Cameron concurred: "This is not about wars in the Middle East. This is not even about the Syrian conflict. It is about the use of chemical weapons and making sure, as a world, we deter their use and we deter the appalling scenes that we've all seen on our television screens." ${ }^{24}$ Although neither the United States nor the United Kingdom suffered any direct injury from Syria's use of chemical weapons against its own people, both claimed authority under international law to use force unilaterally to punish Syria's inhumane actions.

time of the Adra attack, but the Protocol did not apply because it prohibits the use of chemical weapons only in international armed conflict. See Protocol for the Prohibition of the Use of Asphyxiating, Poisonous or Other Gases, and of Bacteriological Methods of Warfare, June 17, 1925, 26 U.S.T. 571, available at https://www.icrc.org/ihl/INTRO/280?OpenDocument.

21 See Additional Protocol I to the Geneva Conventions of August 12, 1949, Relating to the Protection of Victims of International Armed Conflicts art. 51, June 8, 1977, 1125 U.N.T.S. 3 (prohibiting indiscriminate attacks and attacks directed against the civilian population); Int'l Comm. of the Red Cross, Customary International Humanitarian Law Rules, Rule 74 (Jean-Marie Henckaerts \& Louise Doswald-Beck eds., 2005), available at http://www.icrc.org/customaryihl/eng/docs/v1_cha_chapter24_rule74 (characterizing the prohibition against the use of chemical weapons as customary international law applicable during non-international armed conflict).

22 Press Release, The White House, Remarks by the President to the White House Press Corps (Aug. 20, 2012), available at http://www.whitehouse.gov/the-pressoffice/2012/08/20/remarks-president-white-house-press-corps.

23 President Barack Obama, Remarks in Address to the United Nations General Assembly (Sept. 24, 2013), available at http://www.whitehouse.gov/the-pressoffice/2013/09/24/remarks-president-obama-address-united-nations-generalassembly.

24 See Syria: Transcript of PM's Interview, Prime Minister's Office (Aug. 27, 2013), https:/www.gov.uk/government/speeches/syria-transcript-of-pms-interview. 
In the end, military action was averted when Syria unexpectedly agreed to cooperate in the disposal of its chemical weapons stockpiles. Nonetheless, the United States and the United Kingdom did not repudiate their earlier claims that international law would permit them to use force unilaterally as a punitive measure to enforce the international prohibition against chemical weapons attacks. Although neither the United States nor the United Kingdom explicitly invoked Grotius, their arguments for using force against the Assad regime without the Security Council's approval closely tracked Grotius's theory that "a serious crime cannot be unpunishable." 25

Few legal scholars accepted the U.S.-U.K. argument for military intervention in Syria, ${ }^{26}$ and for good reason. Article 2(4) of the U.N. Charter expressly prohibits "the threat or use of force against the territorial integrity or political independence of any state, or in any other manner inconsistent with the Purposes of the United Nations." 27 Although creative interpretations of this provision abound, ${ }^{28}$ Article 2(4) is generally understood to prohibit states from using

25 Grotius, supra note 2, bk. II, ch. 20, pt. II; cf. Chemical Weapon Usage by Syrian Regime: UK Government Legal Position, Prime Minister's Office (Aug. 29, 2013), https://www.gov.uk/government/publications/chemical-weaponuse-by-syrian-regime-uk-government-legal-position (defining conditions for lawful unilateral humanitarian intervention); Harold Hongju Koh, Syria and the Law of Humanitarian Intervention (Part II: International Law and the Way Forward), Just Security (Oct. 2, 2013), http://justsecurity.org/2013/10/02/ koh-syria-part2/ (same).

26 For a sampling of the critical reception, see Oona A. Hathaway \& Scott J. Shapiro, On Syria, A U.N. Vote Isn't Optional, N.Y. Times, Sept. 13, 2013, available at http://www.nytimes.com/2013/09/04/opinion/on-syria-a-unvote-isnt-optional.html?_r=0; Kevin Jon Heller, Four Thoughts on Koh's Defense of Unilateral Humanitarian Intervention, OPINIO JURIS (Oct. 2, 2013), http://opiniojuris.org/2013/10/02/four-thoughts-kohs-defense-unilateralhumanitarian-intervention/; David Kaye, Harold Koh's Case for Humanitarian Intervention, JUST SECURITY (Oct. 7, 2013), http://justsecurity.org/1730/kayekohs-case/; and Carsten Stahn, On 'Humanitarian Intervention, 'Lawmaking' Moments and What the 'Law Ought to Be'-Counseling Caution Against a New 'Affirmative Defense to Article 2(4)'After Syria, Opinio Juris (Oct. 8, 2013), http://opiniojuris.org/2013/10/08/guest-post-humanitarian-interventionlawmaking-moments-law-counseling-caution-new-affirmative-de/.

27 U.N. Charter art. 2(4).

28 A few scholars have argued, for example, that humanitarian intervention without Security Council authorization does not ordinarily transgress Article 2(4), because it is not directed against the "territorial integrity" or "political independence" of the target state and advances the purposes of the United Nations. See, e.g., Fernando R. Tesón, Humanitarian Intervention: An Inquiry into Law and 
force except in cases of "individual or collective self-defense if an armed attack occurs" or pursuant to Security Council authorization "to maintain or restore international peace and security." ${ }^{29}$ Neither of these exceptions to Article 2(4) can plausibly be stretched to permit unilateral punitive action. Nor do general state practice and opinio juris in the Charter era support the idea that international custom would permit states to use force for punitive purposes. ${ }^{30}$

Taking a broader view, resistance to the proposed U.S.-U.K. intervention is consistent with the international community's rejection of Grotius's theory of international punishment. After Grotius advanced his theory, other publicists such as Samuel Pufendorf and Emerich de Vattel raised strenuous objections, arguing that punishment was permissible only within a hierarchical relationship between subject and sovereign, whereas the law governing international relations rested on an entirely different premise: the formal equality of sovereign states. ${ }^{31}$ By the twentieth century, international lawyers had overwhelmingly abandoned Grotius's vision of natural law as a self-standing source of law wholly independent of state consent. ${ }^{32}$ The principle that states could not claim authority over other states without their consent (par in parem non habet imperium) thus became firmly entrenched as a foundational principle of international law. ${ }^{33}$ As a result, there is little support among international

Morality 192-97 (3d ed. 2005); W. Michael Reisman \& Myres McDougal, Humanitarian Intervention to Protect the Ibos, in HUMANITARIAN INTERVENTION AND the United Nations 167, 171-73 (Richard B. Lillich ed., 1973).

29 U.N. Charter arts. 42, 51.

30 See generally Simon Chesterman, Just War or Just Peace? Humanitarian INTERVENTION AND INTERNATIONAL LAW (2001).

31 See VIII Samuel Pufendorf, The Law of Nature and of Nations $\S \S 3,7$ (Basil Kennet trans., 5th ed. London 1749); 2 Emer de Vattel, The LaW of Nations or the Principles of Natural Law Applied to the Conduct and to the Affairs of Nations and of Sovereigns ch. IV $\S 55$ (Joseph Chitty trans., T. \& J.W. Johnson \& Co. 1883) (1758); Christian WolfF, Jus GENTIUM METHOD SCIENTIFICA PERTRACTATUM $\S 169$ (1764), reprinted and translated in 13 The Classics of International LaW 9, 18-19 (James B. Scott ed., Joseph H. Drake trans., 1934). See generally Richard Tuck, The Rights of War and Peace: Political Thought and International Order from Grotius to Kant 158-59 (1999) (discussing Pufendorf's view that punishment could only be administered by "someone with political authority over" another).

32 See Duncan B. Hollis, Why State Consent Still Matters - Non-State Actors, Treaties, and the Changing Sources of International Law, 23 BERKELEY J. INT'L L. 137, 142 (2005) (observing that "most international lawyers still rely on [a positivist doctrine of sources] as international law's operating framework").

33 See, e.g., 1 Lassa Oppenheim, International Law 169 (2d ed. 1912). 
lawyers today for a universal right to use force to punish states for violating international law. ${ }^{34}$

A further problem with relying on Grotius's theory of international punishment is that this approach does not fit naturally with the core purpose of humanitarian intervention, at least as traditionally understood. As Stephen Neff has observed, Grotius's theory of punishment is concerned primarily with "the punishment of the wrong-doer, rather than with the rescue of the victims, which is the chief focus of humanitarian intervention in the modern sense." ${ }^{35}$ To the extent that the Grotian theory of punishment emphasizes other values such as retribution and deterrence, it focuses on a different set of concerns than humanitarian intervention, which aims to secure the safety of human beings from present or imminent threats. For these reasons, among others, recent scholarship has tended to give relatively short shrift to Grotius's punishment theory of international law enforcement as an account of contemporary humanitarian intervention. ${ }^{36}$

\section{Grotius's Guardianship Theory of HUMANITARIAN INTERVENTION}

In contrast to his theory of international punishment, Grotius chose to model humanitarian intervention on the fiduciary relationship between guardians and wards. Grotius begins his account of humanitarian intervention with the observation that the relationship between a sovereign and his subjects shares common features with the parent-child relationship. Like parents, a sovereign bears special responsibility for "the support of his dependents or subjects." Although Grotius expresses skepticism that states are duty-"bound to risk their own safety" to protect a foreign people from oppression, ${ }^{38}$ he nonetheless asserts that states may take up arms to deliver foreign nationals from tyrants who "provoke their people to despair and resistance by unheard of cruelties." 39 Rulers who have "abandoned all the laws of nature" through the inhumane

34 See Blane \& Kingsbury, supra note 6, at 241-43.

35 See Hugo Grotius, On the Law of War and Peace: Student Edition 285 n.32 (Stephen C. Neff ed., 2012) (editor's annotation).

36 For thoughtful reflections on how Grotius's punishment theory has influenced the theory of humanitarian intervention over time, see CHESTERMAN, supra note 30, at 10-13; and Theodor Meron, Common Rights of Mankind in Gentili, Grotius, and Suarez, 85 Ам. J. InT'L L. 110, 110-11 (1991).

37 Grotius, supra note 2, bk. II, ch. 25, pt. I.

38 Id. pt. VII.

39 Id. pt. VIII. 
treatment of their own people "lose the rights of independent sovereigns, and can no longer claim the privilege [of freedom from foreign intervention] under the law of nations." 40 Once the relationship between a state and its people has been ruptured by systematic atrocities, Grotius concludes, other states may use force in order to render temporary "assistance or protection." ${ }^{41}$

Rather than characterize humanitarian intervention as an exercise in punitive law enforcement, Grotius asserts that the law of nature permits intervening states to exercise an oppressed people's natural rights of collective self-defense on their behalf. Under Grotius's account of the law of nations, subjects' duty of fealty to their sovereign means that they lack the legal capacity to redress any mistreatment they may suffer at the hands of their sovereign by force. ${ }^{42}$ This does not, however, leave subjects wholly without recourse. According to Grotius, the legal incapacity that prevents an oppressed people from taking up arms against their sovereign "is of a personal nature"; it is not "inherent in the nature of the action itself." Hence, the duties of fidelity that preclude subjects from taking up arms against their sovereign do not necessarily preclude other powers from interceding on their behalf. Just as the law permits a guardian to undertake an action for a ward, which the ward lacks legal capacity to do for himself, intervening states could take up arms to exercise an oppressed people's natural right to protect themselves collectively from cruel mistreatment. ${ }^{43}$ Thus, under Grotius's guardianship theory, humanitarian intervention constitutes a fiduciary relationship in which a state undertakes to represent the people of another state for the purpose of conducting collective self-defense on their behalf and for their benefit.

Grotius's choice of guardianship as a model for humanitarian intervention was hardly unprecedented. Nearly a century earlier, Francisco de Vitoria had invoked the guardian-ward relationship in his 1532 lecture On the Indians Lately Discovered to explain the circumstances in which the law of nations would permit European states to impose colonial rule in the Americas. Vitoria argued that indigenous peoples in the Americas, being endowed with reason and moral agency, "had true dominion in both public and private matters, just like Christians, and . . . neither their princes nor private persons could be despoiled of their property on the ground of their not being true owners." ${ }^{44}$ Nonetheless, Spanish conquest of the Americas might be justified if first nations

$40 \quad I d$.

41 Id.

42 Id.

43 Id.

44 Francisco de Vitoria, On the Indians Lately Discovered, in De Indis ET DE IVRe Belli Relectiones 128 (Ernest Nys ed., John Pawley Bate trans., 1917). 
violated the natural rights of their Spanish visitors or engaged in "tyrannical and oppressive acts" such as human sacrifice or cannibalism against their own people. ${ }^{45}$ In such cases, other states could intervene as benevolent guardians to guarantee basic security and fundamental rights, subject to a fiduciary obligation to use the power thus conferred for the benefit of the indigenous people. For both Vitoria and Grotius, the fiduciary structure of guardianship offered an intelligible legal and moral framework for humanitarian intervention. Whenever any state ruptured its own fiduciary relationship with its own people through acts of intolerable cruelty, international law entrusted authority to other states to stand in as temporary fiduciaries for the oppressed people for the purpose of exercising a natural right of self-defense on their behalf.

The guardianship theory developed by Vitoria and Grotius highlights salient features of the juridical structure of humanitarian intervention. In private law, fiduciary relationships are generally understood to arise when one party (the fiduciary) undertakes to exercise discretionary power over the legal or practical interests of another (the beneficiary). ${ }^{46}$ Within such relationships, the law obligates the fiduciary to exercise the beneficiary's legal rights on her behalf and for her benefit. Central to Grotius's theory of humanitarian intervention is his argument that the natural law of humanitarian intervention bears a similar formal structure: whenever one state ruptures its own fiduciary relationship with its people, other states possess a residual fiduciary authority to protect foreign nationals, exercising foreign nationals' rights of self-defense on their behalf. Like private-law fiduciaries such as guardians, agents, and trustees, states that engage in humanitarian intervention stand in a legal relationship wherein they are required to use their entrusted powers (the use of force) for a prescribed purpose (defensive action to prevent grave human rights abuse), acting in what they perceive to be the best interests of their beneficiaries (a foreign people). ${ }^{47}$ Thus, in Grotius's view, natural law entrusts states with authority as joint-guardians for humanity to defend foreign nationals who suffer under unconscionable abuse at the hands of their own sovereign.

\section{Id. at 159.}

46 See Paul B. Miller, Justifying Fiduciary Remedies, 63 U. Toronto L.J. 570 (2013).

47 There is some debate in the literature as to whether fiduciaries are required to act in a manner that is objectively in the best interests of their beneficiaries or what they perceive to be their beneficiaries' best interests. See Stephen R. Galoob \& Ethan J. Leib, Intentions, Compliance, and Fiduciary Obligation, 20 LEGAL THEORY 106 (2014); Lionel Smith, Fiduciary Obligations: Ensuring the Loyal Exercise of Judgment on Behalf of Another, 130 L.Q. REv. 608 (2014). I use the latter formulation here, though the argument developed in this Article does not depend upon the distinction. 
Notwithstanding its virtues as an interpretivist theory of humanitarian intervention, Grotius's guardianship theory has several serious weaknesses as applied to contemporary international law. First, the theory is based on controversial natural-law premises. Like Grotius's account of a universal right to punish, the guardianship theory contemplates the existence and jurisprudential authority of a universal law of "right reason" 48 - a premise that has fallen out of fashion in an era dominated by international legal positivism and normative pluralism. ${ }^{49}$ To be sure, natural-law accounts of humanitarian intervention have not disappeared entirely from international legal discourse. ${ }^{50}$ For example, George Fletcher and Jens Ohlin have argued recently that Article 51 of the U.N. Charter preserves and codifies a naturallaw right for states to use force on their own independent initiative for the "legitimate defense" (légitime défense) of human rights victims abroad. ${ }^{51}$ Most experts, however, reject the idea that the Charter's recognition of an "inherent right of self-defense" contemplates unilateral humanitarian intervention. ${ }^{52}$ Moreover, although some legal scholars have advocated recognizing a new norm of unilateral humanitarian intervention following the North Atlantic Treaty Organization's (NATO) 1999 intervention to protect ethnic Albanians in Kosovo, ${ }^{53}$ this proposal has not attracted sufficient support in state practice and opinio juris to generate customary international law. ${ }^{54}$ Hence, even those who support Kosovo-style interventions tend to defend this idea based on appeals to "justice" and respect for "human dignity" rather than international law. ${ }^{55}$ The dominant view among international lawyers today, therefore, is

48 Grotius, supra note 2, bk. I, ch. 1, pt. X.

49 See generally Hollis, supra note 32.

50 See, e.g., William C. Bradford, “The Duty to Defend Them”: A Natural Legal Justification for the Bush Doctrine of Preventive War, 79 Notre Dame L. Rev. 1365 (2004); Michael J. Glennon, The New Interventionism: The Search for a Just International Law, 73 Foreign Aff. 2 (1999); Jens David Ohlin, The Doctrine of Legitimate Defense, 91 InT'L L. STUD. 119 (2015).

51 See George P. Fletcher \& Jens David Ohlin, Defending Humanity: When Force Is Justified AND Why (2008); Ohlin, supra note 50.

52 See, e.g., Saira Mohamed, Restructuring the Debate on Unauthorized Humanitarian Intervention, 88 N.C. L. REv. 1275, 1285-89 (2010); Bruno Simma, NATO, the UN and the Use of Force: Legal Aspects, 10 EuR. J. INT'L L. 1, 3 (1999).

53 See, e.g., Louis Henkin, Kosovo and the Limits of "Humanitarian Intervention," 93 Ам. J. INT'L L. 824, 825 (1999).

54 See Oona A. Hathaway et al., Consent-Based Humanitarian Intervention: Giving Sovereign Responsibility Back to the Sovereign, 46 Cornell InT'L L.J. 499, 521-35 (2013).

55 See, e.g., Glennon, supra note 50. 
that international law prohibits states from unilaterally declaring themselves the guardians of foreign peoples for the purpose of undertaking unilateral humanitarian intervention on their behalf. ${ }^{56}$

Second, any serious effort to translate Grotius's guardianship theory for contemporary international law must come to grips with its dismal historical legacy. Although Vitoria and Grotius introduced the guardianship theory as a framework for safeguarding foreign nationals from domination, Western nations quickly pressed the theory into service as a justification for precisely the opposite purpose: the global expansion of European colonialism and the systematic exploitation of foreign peoples. As Robert Williams has explained, the guardianship concept "provided Western legal discourse with its first secularly oriented, systematized elaboration of the superior rights of civilized Europeans to invade and conquer normatively divergent peoples." ${ }^{57}$ Over time, fiduciary concepts have also supplied a justificatory framing narrative for consolidating and perpetuating power, as European states invoked their "imperious humanitarian duty" to protect vulnerable peoples from the Ottoman Empire during the nineteenth century ${ }^{58}$ and maintained control over former colonies as "mandates" or "trusteeships" in the twentieth century. ${ }^{59}$ In recognition of this troubling history, critics have argued that the guardianship theory of humanitarian intervention serves only to dress up might as right, cementing geopolitical inequality as juridical inequality and thereby facilitating powerful states' neo-imperialist ambitions. ${ }^{60}$

At the close of his discussion of humanitarian intervention in On the Law of War and Peace, Grotius frankly acknowledges the risk that states may

56 See id. at 542-67. A stronger argument can be made that customary international law authorizes states to use countermeasures such as trade restrictions and asset freezes in response to grave human rights abuse abroad. See Evan J. Criddle, Standing for Human Rights Abroad, 100 Cornell L. Rev. 269 (2015).

57 Robert A. Williams, Jr., The American Indian in Western Legal Thought: The Discourses of Conguest 106 (1992).

58 Davide Rodogno, Against Massacre: Humanitarian Interventions in the Ottoman Empire, 1815-1914, at 12, 63-117 (2012); see also Stephen C. NefF, War and the Law of Nations: A General History 224 (2005) (quoting Note to the Porte, 8 Apr. 1830, in CONCERT OF EuROPE 121 (René Albrecht-Carrié ed., 1968)).

59 See League of Nations Covenant art. 22 (mandates); U.N. Charter arts. 75-91 (trusteeships).

60 See Linda Alcoff, The Problem of Speaking for Others, 20 Cultural CritiQue 5 (1991) ("[T] he practice of privileged persons speaking for or on behalf of less privileged persons has actually resulted (in many cases) in increasing or reinforcing the oppression of the group spoken for.”). 
abuse the power reposed in them. Nonetheless, he insists that the potential for abuse does not necessarily undermine the legitimacy of humanitarian intervention generally:

We know ... from both ancient and modern history, that the desire for what is another's seeks such pretexts as this for its own ends; but a right does not at once cease to exist in case it is to some extent abused by evil men. Pirates also sail the sea; arms are carried also by brigands. ${ }^{61}$

This defense of the guardianship theory rings hollow today. If centuries of experience have taught us anything, it is that "pirates" and "brigands" are no less likely than saints to invoke the "right" to humanitarian intervention. ${ }^{62}$ Moreover, even interventions that begin with the best of intentions ultimately may engender a form of foreign domination that undermines self-determination. Hence, Grotius's suggestion that each state may decide for itself whether to engage in humanitarian intervention carries too great a potential for abuse to serve as a model for twenty-first century international law.

In sum, Grotius's theory of humanitarian intervention as a form of legal guardianship has some features that are attractive and others that should give any sober observer pause. On the one hand, the idea that intervening states serve as fiduciaries illuminates the juridical structure of humanitarian intervention in a manner that highlights states' other-regarding obligations to use their power for the benefit of human rights-holders. On the other hand, Grotius's guardianship theory rests on natural-law premises that no longer command general acceptance as an independent legal basis for humanitarian intervention. Furthermore, the fact that the guardianship theory has greased the wheels for colonialist exploitation suggests that the theory is too susceptible to abuse. Even if Grotius's theory captures important features of the juridical structure of humanitarian intervention, it is doubtful that it can be rehabilitated and deployed in a manner that would advance the normative commitments of twenty-first century international society.

\section{The Fiduciary Theory of Humanitarian Intervention}

This Part outlines a new fiduciary theory of humanitarian intervention that better explains the legal basis, purpose, and scope of state authority to protect human rights abroad. This theory takes as its point of departure Grotius's

61 Grotius, supra note 2, bk. II, ch. 25, pt. VIII.

62 See Ryan Goodman, Humanitarian Intervention and Pretexts for War, 100 Ам. J. INT'L L. 107 (2006) (observing that Hitler offered humanitarian arguments "as a pretext for his incursions into Austria and Czechoslovakia"). 
claim that under some circumstances states may use force abroad as temporary fiduciaries for foreign nationals who risk grievous abuse at the hands of their own sovereign..$^{63}$ Although the fiduciary theory owes a significant debt to Grotius, it does not rely upon Grotius's controversial view that states have authority under natural law to use force unilaterally to protect foreign nationals abroad. Instead, the theory proposed uses the fiduciary character of humanitarian intervention as an interpretive framework to explain the character and limits of humanitarian intervention at a time when the Security Council bears exclusive responsibility under the U.N. Charter for authorizing humanitarian intervention without a target state's consent.

At first glance, the Charter's collective-security regime might easily be misconstrued as a wholesale repudation of Grotius's theories of humanitarian intervention. After all, the most striking feature of Grotius's theories of international punishment and humanitarian intervention is the idea that states have authority to act unilaterally under natural law. Conversely, the Charter is generally understood to prohibit the unilateral use of force, except in settings where states are compelled to defend their own people from armed attacks. ${ }^{64}$ States do not, in fact, have a general license to use force abroad unilaterally as agents of global law enforcement (the punishment theory) or as jointfiduciaries for the protection of humanity (the guardianship theory). Despite these fundamental differences, however, Grotius's writings on humanitarian intervention cannot be so easily dismissed, for several reasons.

First, as discussed previously, even if the Charter prevents states from relying on a natural right of humanitarian intervention, Grotius's characterization of humanitarian intervention as a fiduciary relationship remains fundamentally sound today. As Grotius adroitly recognized, humanitarian intervention bears the distinguishing features of a fiduciary relationship; namely, the entrustment of discretionary power over another person's legal interests. ${ }^{65}$ The discretionary powers that states exercise during lawful humanitarian intervention derive from the confluence of two sources: (1) an oppressed people's legal right to defend themselves against grave human rights abuse, ${ }^{66}$ and (2) the Security Council's power under the Charter to authorize action to restore international

63 Grotius, supra note 2, bk. II, ch. 20, pt. VIII.

64 U.N. Charter art. 51. But see Fletcher \& Ohlin, supra note 51; Ohlin, supra note 50 .

65 See Paul B. Miller, The Fiduciary Relationship, in Philosophical Foundations of FidUCiary Law, supra note 10, at 63 (2014).

66 See Ohlin, supra note 50; Jordan J. Paust, International Law, Dignity, Democracy, and the Arab Spring, 46 CoRnell INT'L L.J. 1, 12-14 (2013). 
peace and security ${ }^{67}$ When states exercise authority entrusted to them by the Security Council for the protection of human rights victims abroad, the powers they exercise are not their own; rather, these powers are held in a fiduciary capacity to be exercised for the exclusive benefit of a foreign people. ${ }^{68}$ Grotius's fiduciary conception thus accurately captures the juridical structure of humanitarian intervention.

Viewed from this perspective, the relational character of an intervening state's authority to use force comes into clearer focus. As in other fiduciary relationships, the legal authority that intervening states exercise during humanitarian intervention is other-regarding, purposive, and institutional. ${ }^{69}$ The authority is other-regarding in the straightforward sense that it is legally capable of being exercised only for the benefit of a foreign people, not to advance the self-regarding interests of the intervening state. It is purposive in the sense that it is limited to humanitarian objectives, as specified by the Security Council. And it is institutional in that it generates an institutional relationship between states or regional organizations and the people they seek to protect. This institutional relationship is closely analogous to fiduciary relationships involving court-appointed guardians, successor trustees, and representative plaintiffs in shareholder derivative litigation. In each of these settings, the abuse of power by one fiduciary activates another fiduciary's subsidiary authority to protect the interests of their shared beneficiaries. ${ }^{70}$

67 See Alex J. Bellamy, Responsibility to Protect 63 (2009) (identifying Kofi Annan and Francis Deng as proponents of this approach); ANNE ORFORD, INTERNATIONAL Authority AND the ResPonsibility to Protect 34 (2011) (describing humanitarian intervention as "international executive rule"); Terry Nardin, Introduction, in Humanitarian Intervention: Nomos XLVII 1, 18-21 (2006) (considering humanitarian intervention as an exercise in law enforcement).

68 While a guardian may be thought to exercise a form of parens patriae power by delegation on behalf of the state, this power relates to the ward's legal or practical interests, and the guardian's fiduciary obligations therefore run to the ward, not to the state itself. By the same token, even if states receive their mandate to intervene from the Security Council, they hold this authority in a fiduciary capacity and are required to exercise their authority for the benefit of an oppressed people.

69 See Evan J. Criddle \& Evan Fox-Decent, A Fiduciary Theory of Jus Cogens, 34 Yale J. InT'L L. 331 (2009).

70 This account of the juridical basis for humanitarian countermeasures resonates with Eyal Benvenisti's vision of states as “trustees of humanity.” See Eyal Benvenisti, Sovereigns as Trustees of Humanity: On the Accountability of States to Foreign Stakeholders, 107 Am. J. INT'L L. 295 (2013). 
The juridical structure of humanitarian intervention thus supports Grotius's argument that intervening states exercise authority as fiduciaries.

Second, requiring Security Council authorization for the use of force is fully consistent with a fiduciary conception of humanitarian intervention. ${ }^{71}$ This is true irrespective of whether the use of force in humanitarian intervention is best understood as deriving from an oppressed people's collective right of self-defense or from the Security Council's power under the Charter "to take such action ... as may be necessary to maintain or restore international peace and security." 72 Under both accounts, Security Council approval serves as the mechanism for entrusting authority to states to intercede in defense of an oppressed people for their benefit. Just as individuals must obtain judicial approval before they may serve as legal guardians for children who have suffered abuse at the hands of their parents, the U.N. Charter requires states to obtain Security Council approval before they may assume responsibility for using force abroad to protect foreign nationals. This requirement of positive authorization marks a significant departure from Grotius's original naturalist theory, but it is fully consistent with his insight that intervening states stand in a fiduciary relationship with the intended beneficiaries of humanitarian intervention.

Third, the fiduciary theory also clarifies the controversial R2P principle, which suggests that when states are unable or unwilling to protect their own people from grave human rights abuse, the international community as a

71 Since the early 1990s, the Security Council has authorized humanitarian intervention on a number of occasions, including in Somalia, Bosnia-Herzegovina, East Timor, Sierra Leone, and Libya. See, e.g., S.C. Res. 1973, 19 4, 8, U.N. Doc. S/RES/1973 (Mar. 17, 2011) (authorizing air strikes to enforce a no-fly-zone and prevent war crimes and crimes against humanity in Libya); S.C. Res. 1270, U.N. Doc. S/RES/1270 (Oct. 22, 1999) (establishing the U.N. Mission in Sierra Leone (UNAMSIL) to keep peace and ensure the delivery of humanitarian aid); S.C. Res. 1264, U.N. Doc. S/RES/1264 (Sept. 15, 1999) (authorizing a multinational force to restore peace in East Timor); S.C. Res. 758, U.N. Doc. S/RES/758 (June 8, 1992) (authorizing the U.N. Protection Force (UNPROFOR) in the former Yugoslavia to take steps to ensure the delivery of humanitarian aid to Sarajevo). Although the Charter does not provide expressly for the Security Council to authorize military intervention to prevent human rights abuses confined within a single state's borders, the international community has accepted this principle as part of the Security Council's authority "to maintain or restore international peace and security" under U.N. Charter art. 42.

72 U.N. Charter art. 42. 
whole bears a subsidiary responsibility to furnish protection and assistance. ${ }^{73}$ Proponents of R2P argue that the international community may satisfy R2P in most settings by providing material assistance and training to strengthen a state's capacity to protect its own people. When such measures prove to be inadequate, however, the international community may use force to prevent large-scale human rights disasters such as those that unfolded in Rwanda and Darfur. ${ }^{74}$

Over time, the U.N. Security Council, the Secretary General, and the General Assembly have all expressed support for R2P, affirming that individual states and the international community collectively are assigned complementary roles in preventing mass atrocities. ${ }^{75}$ Nonetheless, R2P continues to stir debate among international lawyers and political theorists. Some critics have faulted R2P for assigning protective responsibility to the nebulous "international community" without specifying what obligations and authority, if any, particular states and international organizations have to protect human rights abroad. ${ }^{76}$ Other scholars have argued that R2P has little direct relevance for international law, because it is merely an expression of the international community's collective political commitment to guaranteeing human security rather than a binding legal obligation to take action in response to humanitarian crises. ${ }^{77}$

73 See, e.g., Int'l Comm. on Intervention \& State Sovereignty, The Responsibility то Рвотест 13, $\uparrow 2.15$ (2001) (“[S]tate authorities are responsible for the functions of protecting the safety and lives of citizens and promotion of their welfare."); Francis M. Deng et al., Sovereignty as Responsibility: Conflict Management IN AFricA, at xii, xvii (1996) (characterizing the international community as "the ultimate guarantor of the universal standards that safeguard the rights of all human beings"); Catherine Powell, Libya: A Multilateral Constitutional Moment?, 106 Ам. J. InT'L L. 298 (2012).

74 See World Summit Outcome, supra note 11, ๆ 139.

75 See Kofi Annan, Two Concepts of Sovereignty, Economist (Sept. 18 1999), http://www.economist.com/node/324795; U.N. Secretary-General, Implementing the Responsibility to Protect, U.N. Doc. A/63/677 (Jan. 12, 2009); World Summit Outcome, supra note 11, 1 138-39; S.C. Res. 1970, U.N. Doc. S/RES/1970 (Feb. 26, 2011); S.C. Res. 1973, supra note 71; S.C. Res. 1674, ๆ 4, U.N. Doc. S/RES/1674 (Apr. 28, 2006).

76 See, e.g., James Pattison, Humanitarian Intervention and the Responsibility to Protect: Who Should Intervene? 4 (2010); William W. Burke-White, The Adoption of the Responsibility To Protect, in The Responsibility to Protect: The Promise of Stopping Mass Atrocities in Our Time 17 (Jared Gensler \& Irwin Cotler eds., 2011).

77 See, e.g., Alex J. Bellamy, The Responsibility to Protect: A Defense 13-14 (2015); Aiden Hehir, The Responsibility to Protect: Sound and Fury Signifying Nothing, 24 INT'L REL. 218, 218-19, 234-35 (2010). 
The fiduciary theory reorients R2P in a manner that irons out some of the wrinkles in contemporary debates. The fiduciary theory suggests that R2P does have legal significance, because the principle affirms that human rights protection does not fall within the exclusive jurisdiction of national authorities. ${ }^{78}$ International institutions such as the Security Council also serve as indirect guardians of humanity with authority to take action when states do not honor their fiduciary obligations to their people. Rather than encumber the Security Council or the "international community as a whole" with an affirmative duty to intervene, however, R2P operates primarily as a power-conferring gloss on the U.N. Charter, affirming the Security Council's authority to approve humanitarian intervention by U.N. member-states over a target state's objections. ${ }^{79}$ When mass atrocities prompt calls for military action, the responsibility to provide direct protection is assumed voluntarily by states and regional organizations that are entrusted with this authority by the Security Council. ${ }^{80}$ Just as an individual must consent to serve as guardian for a ward or a trustee for beneficiaries, states and regional organizations are under no legal obligation to place their armed forces in harm's way to protect a foreign people from their own government. ${ }^{81}$ Once a state or regional organization voluntarily assumes this responsibility as a direct guardian for an oppressed people abroad, however, the fiduciary theory supports the idea

78 See Bellamy, supra note 77, at 95 (observing that prior to the 2011 NATO intervention in Libya, humanitarian interventions authorized by the Security Council had always received the target state's consent).

79 See ORFORD, supra note 67, at 25-26 (arguing that R2P is best understood as a power-conferring rule rather than a duty-imposing rule). The fiduciary theory is compatible, however, with the idea that the Security Council bears an affirmative obligation to authorize intervention when necessary and appropriate to prevent an imminent humanitarian crisis. Cf. Anna Spain, The U.N. Security Council's Duty to Decide, 4 Harv. Nat'L Security J. 320 (2013) (arguing that the Security Council should be charged with an affirmative, quasi-judicial "duty to decide").

80 Although the U.N. Charter originally provided for states by "special agreement" to contribute "armed forces, assistance, and facilities" for a standing international security force under the Security Council's command, see U.N. Charter art. 43, this provision has remained dormant. U.N. agencies have played a more direct role, however, in helping states and regional organizations to develop and sustain the capacity for durable human rights protection through peacekeeping and other missions. See ORFORD, supra note 67, at 209 (arguing that U.N. peacekeeping operations represent the paradigm case for R2P).

81 See Grotius, supra note 2, bk. II, ch. 20, pt. VII. But see Monica Hakimi, Toward a Legal Theory of the Responsibility To Protect, 39 YALE J. InT'L L. 247 (2014) (arguing that some states may assume responsibility to intervene abroad based on their contribution to humanitarian crises). 
that intervening forces must use their entrusted power in a manner that is consistent with the $\mathrm{R} 2 \mathrm{P}$ principle. In each of these respects, the fiduciary theory helpfully disentangles R2P's legal and political dimensions.

The Security Council's 2011 resolution authorizing humanitarian intervention in Libya offers the clearest illustration of the fiduciary theory in action. While "reaffirming that parties to armed conflicts bear the primary responsibility to take all feasible steps to ensure the protection of civilians," the Security Council concluded that international intervention was warranted to address the Libyan government's indiscriminate attacks against civilians. ${ }^{82}$ The Security Council therefore authorized "Member States that have notified the SecretaryGeneral, acting nationally or through regional organizations or arrangements, and acting in cooperation with the Secretary-General, to take all necessary measures ... to protect civilians and civilian populated areas under threat of attack." ${ }^{13}$ The Security Council thus entrusted states with authority to use force in a fiduciary capacity for the limited purpose of defending civilians in Libya from war crimes and crimes against humanity. With this mandate in hand, NATO countries commenced a campaign of air strikes and cruise missile attacks to prevent the Libyan government from perpetrating further human rights abuses. ${ }^{84}$

Requiring international authorization for humanitarian intervention provides an important institutional check against powerful states proclaiming themselves the rightful "guardians" for foreign peoples and using force without adequate justification. ${ }^{85}$ But is this requirement sufficient to ensure that humanitarian intervention will be used only where strictly necessary and in a manner that is faithful to the interests of an oppressed people? Surely not. Once authority for intervention has been conferred upon a state or group of states, further checks are needed to hedge against the risk of abuse. These checks should be carefully calibrated to promote accountability without unduly constraining intervening states' capacity for effective action.

Although enthusiasts of the R2P doctrine have pointed to the NATO-led intervention in Libya as a promising example of U.N.-authorized humanitarian intervention, ${ }^{86}$ it also serves as a cautionary tale. NATO intervention may

82 S.C. Res. 1973, supra note 71, pmbl.

83 Id. pmbl. $\uparrow$ - 4-8.

84 Libya: US, UK and France Attack Gaddafi Forces, BBC News (Mar. 20, 2011), http://www.bbc.com/news/world-africa-12796972.

85 See Alex J. Bellamy, Responsibility to Protect or Trojan Horse? The Crisis in Darfur and Humanitarianism After Iraq, 19 Eтнісs \& InT'L Aff. 31 (2005) (observing that the 2003 Iraq War undermined the credibility of the United States and the United Kingdom as agents for humanitarian intervention).

86 See, e.g., Powell, supra note 73. 
have averted massive civilian casualties in some areas of Libya, ${ }^{87}$ but NATO members soon expanded the operation in ways that extended far beyond their mandate from the Security Council. By supplying arms and other assistance to rebel militia groups and by targeting Libyan forces and infrastructure that were not involved in attacks against civilians, the NATO-led mission decisively shifted the balance of power in Libya's civil war, paving the way for regime change. ${ }^{88}$ NATO also flouted the Security Council's express call for a negotiated solution to the crisis by rebuffing the Libyan regime's efforts to negotiate. ${ }^{89}$ While scholars might debate whether NATO's efforts to bolster the Libyan insurgency advanced the interests of the Libyan people in the long run, there can be little doubt that in a variety of respects NATO forces exceeded the scope of their mandate from the Security Council.

The Libya intervention thus poses an important challenge to the fiduciary theory. For the fiduciary theory to have credibility, it is critical that international law regulate not only who may engage in humanitarian intervention, but also how they may do so. ${ }^{90}$ And the international community needs to develop more effective procedures for holding states accountable when they abuse their entrusted authority during humanitarian intervention.

\section{Operationalizing the Fiduciary Theory}

This Part proposes three specific measures to make the fiduciary theory of humanitarian intervention more credible in practice. First, intervening states must respect a foreign people's right to self-determination by making goodfaith efforts to consult with and respect the actual preferences of the people for whose benefit they purport to act. Second, states that engage in humanitarian intervention must use force in a manner that respects the requirements of international human rights law (IHRL), including the heightened proportionality requirements associated with the human "right to life." ${ }^{91}$ Third, the Security Council must become a more effective oversight body for humanitarian intervention, not only with respect to the Security Council's oft-criticized decision-making structure, but also with respect to how the Security Council designs its authorizing resolutions ex ante and supervises intervention ex

87 See Bellamy, supra note 77, at 187.

88 Id. at $187-89$.

89 Id. at 187.

90 See id. at 189 (discussing Brazil's proposal for a new "responsibility while protecting" principle that would focus attention on the international community's responsibilities during implementation of R2P).

91 ICCPR, supra note 12, art. 6.1. 
post. These three proposals are not meant to be exhaustive; other reforms will surely be needed to fully operationalize the fiduciary theory of humanitarian intervention. Nonetheless, these proposals illustrate how the fiduciary theory might enhance the normative coherence and legitimacy of humanitarian intervention in practice.

\section{A. The Duty of Deliberative Engagement}

A major weakness of Grotius's guardianship model for humanitarian intervention is that it treats human rights-holders as mere passive objects of state concern, not as autonomous agents whose idiosyncratic values and preferences are entitled to respect. As discussed previously, critics have observed that the paternalistic character of humanitarian intervention raises "the spectre of potential neo-colonialism." ${ }^{92}$ In response to these concerns, advocates of the $\mathrm{R} 2 \mathrm{P}$ doctrine have argued that the international community needs to consider "the problem from the victim's point of view" and focus "on rebuilding [humanitarian intervention] around local empowerment." 93 Thus, the R2P movement has endeavored to shift the international community's attention away from international military action toward measures that can be taken before a crisis arises to strengthen states' commitment and capacity to respect and protect human rights.

Less attention has been paid to what it would mean for states to consider "the victim's point of view" when they contemplate military intervention. Taking seriously the victim's point of view could simply mean that states must give due regard to how military intervention would impact foreign nationals' legitimate, legally protected interests. At a minimum, states might engage in reasoned deliberation to determine whether military intervention would serve the best interests of a foreign people, taking into account factors such as the impact that military intervention would likely have upon human security, infrastructure, and economic development within the target state. ${ }^{94}$ This approach is consistent with a fiduciary theory of humanitarian intervention,

92 Bellamy, supra note 77 , at 43.

93 Id. at 43-44 (describing the approach of the International Commission on Intervention and State Sovereignty).

94 This approach resonates with Edmund Burke's much-criticized trusteeship conception of political representation, wherein a "natural aristocracy" would determine what policies and programs would best advance the interests of their constituents. Edmund Burke, The French Revolution, in Burke's Politics: Selected Writings and Speeches of Edmund Burke on Reform, Revolution, AND WAR 277, 397-98 (Ross J.S. Hoffman \& Paul Levack eds., 1949) (1770). 
because the duties of loyalty and care require fiduciaries to consider and prioritize the best interests of their beneficiaries.

Alternatively, taking the victim's point of view could mean that an intervening state must endeavor to ascertain and honor the actual preferences of their beneficiaries. Many fiduciary relationships such as agent-principal and lawyer-client require fiduciaries to consult with their beneficiaries and follow their actual preferences when critical decisions arise. ${ }^{95}$ These fiduciary relationships, which seek to empower beneficiaries to control their fiduciaries' performance, arguably provide a better model for humanitarian intervention than Grotius's guardianship analogy. As David Ponet and Ethan Leib have observed, fiduciary law contains "a constellation of obligations that can be read to require 'deliberative engagement." 96 These obligations of deliberative engagement include the fiduciary duty of loyalty, which dictates that beneficiaries must give informed consent to any conflicts of interest. ${ }^{97}$ The duty of care likewise requires public fiduciaries to "consult with and deliberatively engage constituents as part of the process of rationally considering their preferences and assessing the full panoply of potential courses of action within the public fiduciary's authorization." 98 In the context of humanitarian intervention, these deliberative features of fiduciary law underscore the idea that intervening states must demonstrate solicitude for the actual values and preferences of the foreign peoples they purport to represent. For example, a plausible implication of the fiduciary theory is that states may not conduct military intervention without Security Council authorization unless they have sought human rights victims' consent to foreign assistance, and they should not use force if such measures would be inconsistent with the express preferences of the human rights-holders whom they purport to represent. Thus, a serious effort to respect the preferences of a foreign people is arguably required by the idea of "taking the victim's point of view."

95 See, e.g., Restatement (Third) of Agency $§ 1.01$ cmt. f (2005) (“An essential element of agency is the principal's right to control the agent's actions."); Carol A. Needham, Advance Consent to Aggregate Settlements: Reflections on Attorneys' Fiduciary Obligations and Professional Responsibility Duties, 44 Loy. U. CHI. L.J. 511, 514 (2012) (observing that a lawyer's duty of loyalty includes obligations to "communicate effectively with the client regarding the representation, and consult with the client regarding the matters essential to the representation" (citations omitted)).

96 David L. Ponet \& Ethan J. Leib, Fiduciary Law's Lessons for Deliberative Democracy, 91 B.U. L. Rev. 1207, 1215 (2011).

97 Id. at 1215-16.

98 Id. at $1216-17$. 
This requirement of deliberative engagement resonates with similar requirements in other fields of international law where states stand in fiduciary relationships with their own citizens or foreign nationals. For example, the U.N. International Law Commission has concluded that when states espouse the claims of their nationals for the purpose of asserting legal claims on their behalf, they must "take into account, wherever feasible, the views of injured persons with regard to resort to diplomatic protection and the reparation to be sought." ${ }^{99}$ Likewise, the international law of indigenous rights, another regime that has been shaped by fiduciary concepts, obligates states to "consult and cooperate in good faith with . . indigenous peoples ... through their own representative institutions in order to obtain their free, prior and informed consent before adopting and implementing legislative or administrative measures that may affect them." ${ }^{100}$ Whenever a state exercises public powers on behalf of others, it bears a corresponding fiduciary obligation to ascertain and respect the preferences of its beneficiaries. ${ }^{101}$

The requirement of deliberative engagement poses a nettlesome challenge for humanitarian intervention, however, because it is often difficult for the international community to find and access appropriate "representative institutions" when a people faces a threat from their own state. Where a host state seeks to commit crimes against humanity against a discrete and wellorganized political party, ethnic group, or religious community, identifying

99 Draft Articles on Diplomatic Protection with Commentaries, art. 19(b), Int'1 Law Comm'n, 58th Sess., May 1-June 9, July 3-Aug. 11, 2006, U.N. GAOR, 61st Sess., Supp. No. 10, A/61/10 (2006).

100 Declaration on the Rights of Indigenous Peoples art. 19, G.A. Res. 61/295, U.N. Doc. A/RES/61/295 (Sept. 13, 2007); cf. Saramaka People v. Suriname, Judgment, Inter-Am. Ct. H.R. (Ser. C) No. 172, \ 134 (Nov. 28, 2007) (requiring good-faith consultation and informed consent for large-scale development or investment projects); Convention Concerning Indigenous and Tribal Peoples in Independent Countries (Convention No. 169), June 27, 1989, 28 I.L.M. 1382 (providing that states must honor "the social, cultural, religious and spiritual values and practices of [indigenous] peoples"; "consult the peoples concerned ... whenever consideration is being given to ... measures which may affect them directly"; and conduct these consultations "in good faith and in a form appropriate to the circumstances, with the objective of achieving agreement or consent to the proposed measures"). See generally Evan Fox-Decent \& Ian Dahlman, Sovereignty as Trusteeship and Indigenous Peoples, 16 THEORETICAL INQUIRIES L. 507 (2015).

101 For more detailed treatments of this principle, see Evan J. CRiddLE \& Evan FoxDecent, International LaW's Fiduciary Constitution (forthcoming 2015); and Evan Fox-Decent, Sovereignty's Promise: The State as Fiduciary (2011). 
the appropriate opposition leaders for deliberative engagement may be a relatively straightforward matter, and it is critical that intervening states obtain these representatives' free and informed consent for military intervention. If representatives of an oppressed group request the modification or discontinuation of humanitarian intervention, intervening states should make every effort to respect these requests, provided that they can do so within the constraints of the Security Council's relevant resolutions.

Conversely, where a vulnerable group lacks effective representation, deliberative engagement may prove to be a more complex challenge. In the current Syrian civil war, for example, it is unclear which antigovernment factions, if any, best represent the values and preferences of Syrians whose lives have been jeopardized by the Assad regime's war crimes and crimes against humanity. In such settings, the duty of deliberative engagement would require intervening states to make public their proposed action with a statement of the humanitarian rationale for intervention. Intervening states would also bear a responsibility to engage a broad spectrum of stakeholders in order to make a fully informed and rational decision that reflects due regard for the interests of all. Irrespective of the setting, intervening states must create spaces for foreign nationals to contest whether and how intervening states may use force on their behalf. ${ }^{102}$

The fiduciary theory's requirements of deliberative engagement mark an important advance over Grotius's punishment and guardianship theories of humanitarian intervention, which commit enforcement to the intervening state's unilateral discretion. To the extent that states intervene on behalf of others, they bear a fiduciary obligation to proceed deliberatively, seeking out and giving due regard to the preferences of their intended beneficiaries.

\section{B. The Human Right to Life}

The fiduciary theory also has important implications for how states use force when they conduct humanitarian intervention. In particular, because international law entrusts intervening states with authority to use force for the benefit of an oppressed people, intervening states bear a fiduciary obligation to observe human rights standards for the use of force whenever they engage in humanitarian intervention. ${ }^{103}$

102 See Robert H. Sitkoff \& Jesse Dukeminier, Wills, Trusts \& Estates 653, 657 58 (9th ed. 2013) (observing that the "duty of impartiality" in trust law requires "due regard" to the beneficiaries' respective interests).

103 Elsewhere I have argued that the fiduciary character of a state's relationship with its own people and foreign peoples under its authority also requires the 
In recent years, an energetic debate has arisen among legal scholars concerning how standards from IHRL and international humanitarian law (IHL) interact during armed conflict. ${ }^{104}$ International human rights tribunals and the International Court of Justice have become increasingly receptive to the idea that human rights norms apply during armed conflict, creating areas of jurisdictional overlap and potential normative conflict. ${ }^{105}$ For example, IHRL and IHL offer distinct accounts of who may be targeted and the circumstances in which lethal forced may be used. Under the IHL principle of distinction, a state in armed conflict need not establish that any particular enemy combatant poses an imminent threat to their own security; the mere fact that an enemy combatant has taken direct part in hostilities against the state is sufficient to qualify them as a legitimate target for the use of lethal force. ${ }^{106}$ IHL's "principle of proportionality in attack" 107 provides that states are free to conduct attacks that are "expected to cause incidental loss of civilian life, injury to civilians, damage to civilian objects, or a combination thereof," as long as such collateral damage is not manifestly "excessive in relation to the concrete and direct military advantage anticipated." 108

IHRL standards for the use of force are considerably more restrictive, both with respect to who may be targeted and the type of force that may be employed. The human "right to life" prohibits states from using lethal force unless they can show that this measure is "absolutely necessary" to protect

application of human rights constraints on the use of force. See Evan J. Criddle, Proportionality in Counterinsurgency: A Relational Theory, 87 Notre DAmE L. REv. 1073 (2012).

104 See, e.g., International Humanitarian Law and International Human Rights LAw (Orna Ben-Naftali ed., 2011) (providing a useful survey of these debates).

105 See, e.g., Legal Consequences of the Construction of a Wall in the Occupied Palestinian Territory, Advisory Opinion, 2004 I.C.J. 136, 178 (July 9); Isayeva v. Russia, 41 Eur. Ct. H.R. 39 (2005); Bámaca-Velásquez v. Guatemala, Merits and Judgment, Inter-Am. Ct. H.R. (ser. C) No. 70, ๆ 209 (Nov. 25, 2000).

106 See Geneva Convention (III) Relative to the Treatment of Prisoners of War art. 3, Aug. 12, 1949, 6 U.S.T. 3316, 75 U.N.T.S. 135; Additional Protocol I to the Geneva Conventions of August 12, 1949, Relating to the Protection of Victims of International Armed Conflicts arts. 40-41, June 8, 1977, 1125 U.N.T.S. 3 [hereinafter API].

107 Int'l Comm. of the Red Cross, Customary International Humanitarian LaW Rules ch. 4, rule 14 (Jean-Marie Henckaerts \& Louise Doswald-Beck eds., 2005), available at http://www.icrc.org/customary-ihl/eng/docs/v1.

108 API, supra note 106, art. 51(5)(b). 
human life or legal order. ${ }^{109}$ States must take precautions to avoid or minimize casualties "to the greatest extent possible," 110 and they may use lethal force only if nonlethal measures such as arrest or incapacitation would be likely to impose disproportionate injury. ${ }^{111}$ Moreover, IHRL's proportionality principle requires states to consider all potential casualties - lawful combatants, noncombatant fighters, and ordinary citizens alike - when planning and executing operations that involve the use of force, ${ }^{112}$ whereas military casualties are irrelevant to IHL's proportionality inquiry. ${ }^{113}$ By limiting the use of lethal force and extending this constraint to all human beings, combatants and noncombatants alike, IHRL permits states to use force under a significantly narrower set of circumstances than IHL.

The fiduciary theory of humanitarian intervention suggests that IHRL's more restrictive standards for the use of force should apply whenever states use force to protect the human rights of foreign nationals abroad. As fiduciaries entrusted with the responsibility to protect human rights, intervening states bear a special responsibility to avoid using force in a manner that exceeds this mandate. In particular, the fiduciary character of the relationship between an intervening state and a foreign people suggests that states must take care to avoid inflicting any harm that is not strictly necessary to fulfill their entrusted responsibility to guarantee basic security under the rule of law. Merely ensuring that collateral injury to noncombatants is not "excessive" in relationship to an intervening state's military objectives is insufficient, given that the purpose of humanitarian intervention is to protect international human rights, which include the right to life. Nor may an intervening state use lethal force against foreign combatants unless such action is strictly necessary to prevent grave human rights abuse. These requirements flow naturally from the fiduciary theory's

109 See Council of Europe, Convention for the Protection of Human Rights and Fundamental Freedoms art. 2(2), Nov. 4, 1950, E.T.S. No. 5, 213 U.N.T.S. 221; McKerr v. United Kingdom, 2001-III Eur. Ct. H.R. 475, 516-17 110 (2001); Human Rights Committee, General Comment No. 6, qा 3, 129, 16th Sess., 37 U.N. GAOR, Supp. (No. 40), U.N. Doc. A/37/40 (1982).

110 Isayeva, 41 Eur. Ct. $\ 175$.

111 See, e.g., Khatsiyeva v. Russia, App. No. 5108/02, Eur. Ct. H.R. (2008).

112 See David S. Koller, The Moral Imperative: Toward a Human Rights-Based Law of War, 46 Harv. InT'L L.J. 231, 260-61 (2005); Kenneth Watkin, Controlling the Use of Force: A Role for Human Rights Norms in Contemporary Armed Conflict, 98 Ам. J. INT'L L. 1, 32 (2004).

113 See Yoram Dinstein, The Conduct of Hostilities Under the Law of International Armed Conflict 129 (2d ed. 2010) ("Proportionality has nothing to do with injury to combatants or damage to military objectives.”). 
formal legal requirement that states conducting humanitarian intervention must treat foreign nationals always as equal beneficiaries of their coercive power. ${ }^{114}$

Under the fiduciary theory, intervening states may assume human rights obligations toward foreign nationals even if they do not exercise effective control over foreign territory. The assumption of coercive power over foreign territory as fiduciary for foreign nationals is sufficient to trigger the obligation to respect human rights.

This principle has not been uniformly accepted, despite the fact that the two clearest examples of multilateral humanitarian intervention from the past fifteen years, Kosovo (1999) and Libya (2011), both involved humanitarian airstrikes without intervening states "putting boots on the ground." In the 2001 case Bankovic v. Belgium, the European Court of Human Rights considered whether this type of intervention triggered state responsibility under the European Convention on Human Rights. ${ }^{115}$ At issue in the case was a NATO airstrike against television and radio production facilities in Belgrade that had claimed sixteen lives and seriously wounded an equal number of others. ${ }^{116}$ Emphasizing the contractual character of the European Convention, the Court held that the airstrike did not fall within the Convention's scope, because the intervening states lacked "effective control of the relevant territory and its inhabitants." 117

The fiduciary theory, in contrast, suggests that states conducting humanitarian intervention assume human rights obligations toward foreign nationals regardless of whether or not they obtain effective control over a foreign people or foreign territory. More consistent with the fiduciary theory is an alternative approach that the Court articulated several years later in Issa v. Turkey: if a state claims "authority" over foreign people or territory (as during humanitarian intervention) the heightened requirements of IHRL apply. ${ }^{118}$ Respect for human rights is a requirement that accompanies any use of force by a state that purports to engage in humanitarian intervention. An important contribution of the

114 But see Jeff McMahan, The Just Distribution of Harm Between Combatants and Noncombatants, 38 PHIL. \& PuB. Aff. 342, 359-61 (2010) (arguing that the beneficiaries of military action may be subjected to greater harm than other persons because "the risks of defensive action ought to be borne by those who stand to benefit from" measures that are designed to reduce their overall risk of harm).

115 Bankovic v. Belgium, 2001-XII Eur. Ct. H.R. 333, 346 \ 34 (posing the question whether mere airstrikes entailed an exercise of "jurisdiction" under Article 1 of the European Convention).

$116 \mathrm{Id}$. at 340-41 9 -9 $9-11$.

117 Id. at 355 - 71, 358-59 80.

118 Issa v. Turkey, App. No. 31821/96, 41 Eur. H.R. Rep. 567 ๆ 72 (2004). 
fiduciary theory, therefore, is to call into question the idea that intervening states may treat humanitarian intervention as ordinary international armed conflict, subject to IHL's general principles of distinction, necessity, and proportionality. Whenever states conduct humanitarian intervention (with or without a host state's consent), they assume a correlative obligation to use force in a manner that fully respects the human right to life.

\section{Security Council Oversight}

Given the grave injustices that states have perpetrated against one another in the name of humanitarian "guardianship," robust international institutions are essential to guarantee the fiduciary obligations associated with humanitarian intervention. Requiring states to obtain approval from either the target state itself or the Security Council when initiating humanitarian intervention provides some assurance that intervening states will possess the capacity and commitment to serve as faithful fiduciaries for foreign nationals. After authority for humanitarian intervention has been entrusted to particular states, continuing international review is necessary to ensure that the states do not abuse their discretionary power for self-interested purposes. In short, the fiduciary theory presupposes the existence of international institutions that are capable of holding states accountable for violating their fiduciary obligations.

Unfortunately, the Security Council's flawed decision-making structure has compromised its ability to perform this function effectively. The Security Council has often lacked the political will to approve intervention in response to even the most serious humanitarian crises. Moreover, because the Security Council's veto-wielding permanent members (P5) generally play key roles in conducting U.N.-approved humanitarian interventions, the Security Council is poorly equipped to curb interventions that exceed the scope of states' entrusted authority. As reflected in the U.S.-led military actions in Iraq (2003) and Libya (2011), narrowly tailored Security Council resolutions can easily be reinterpreted as open-ended licenses for the use of force. Once a P5 state has received a mandate for humanitarian intervention, this mandate is virtually impossible to withdraw through a new resolution. This accountability deficit has made it more difficult for states advocating humanitarian intervention (chiefly, the United States and the United Kingdom) to persuade other P5 states (chiefly, China and Russia) to support Security Council resolutions authorizing intervention. The accountability deficit also provides fodder for critics who argue that the lofty rhetoric of "humanitarianism" and "fiduciary duty" merely serves as a pretext for great-power domination. In the long run, the Security Council will need to develop new and better ways to supervise humanitarian intervention if the fiduciary theory is to be credible in practice. 
Pending more fundamental reform of the Security Council's decisionmaking structure, some relatively modest changes could significantly narrow the current accountability deficit. One commonsense reform, which Brazil has proposed in the wake of NATO's intervention in Libya, would be to establish standardized reporting and review procedures to enable the Security Council to continuously "monitor and assess the manner in which resolutions are implemented" and thereby provide for "the accountability of those to whom authority is granted to resort to force." 119 The Security Council could also establish its own independent monitoring body to investigate complaints that intervening states have exceeded their mandates. ${ }^{120}$ While such oversight procedures would require the Security Council to devote more resources to monitoring and could risk further politicizing humanitarian interventions, ${ }^{121}$ the requirement that intervening states provide a regular accounting for their use of force flows directly from the fiduciary character of their entrusted authority.

A second option for enhancing Security Council oversight would be to include a provision in future Security Council resolutions allowing the Security Council or a separate committee composed of Security Council members to narrow or withdraw mandates for humanitarian intervention by a simple majority vote, narrowing the threat of a $\mathrm{P} 5$ veto. This mechanism could deter states from undertaking humanitarian intervention in the first place by raising the possibility that the Security Council could seek to micromanage their military engagements or cancel a mission prematurely after an intervening state has already committed significant resources. On the other hand, allowing the Security Council to withdraw its mandate for humanitarian intervention by a simple majority would help to counter the threat of "mission creep" by enabling the Security Council to rein in intervening states that exceed the scope of their entrusted authority.

Should this option prove impracticable, the Security Council could achieve a similar result by adding "sunset provisions" — clauses that provide a fixed expiration date - to resolutions that authorize humanitarian intervention. ${ }^{122}$ In other settings, lawmakers have used sunset provisions to promote flexible and responsive governance, ${ }^{123}$ and similar objectives could be achieved by requiring

119 Bellamy, supra note 77, at 192 (quoting Letter from the Permanent Representative of Brazil, to the U.N. Secretary-General (Nov. 9, 2011)).

120 See id. at 201.

121 Id. at 199.

122 See id. at 200 (observing that sunset clauses are "standard practice for UN peacekeeping operations").

123 See Rebecca M. Kysar, The Sun Also Rises: The Political Economy of Sunset Provisions in the Tax Code, 40 GA. L. Rev. 335, 337 (2006). 
states to seek periodic reauthorization for humanitarian intervention. While the duration of the sunset period would obviously have to be calibrated to the scope of the anticipated intervention, a sunset period in the range of sixty to ninety days should give intervening states sufficient scope for action to avert an impending humanitarian crisis (e.g., Kosovo, Libya), while preventing the exigencies of the moment from generating an open-ended mandate for a sustained foreign military presence in the target state. Requiring periodic Security Council reauthorization would compel intervening states to account for their performance, while also helping to ensure that their actions are consistent with fiduciary principles of integrity, impartiality, and solicitude. Should an intervening state abuse its discretion, the Security Council could decline to renew its authorization for the use of force, or it could issue a revised mandate that would define the humanitarian mission more precisely or transfer responsibility for intervention to other states. The Security Council could also establish U.N.-sponsored institutions to facilitate deliberative engagement between intervening states and representatives of oppressed peoples. While these are not the only conceivable mechanisms for enhancing international accountability for humanitarian intervention, they are suggestive of the kinds of sensible reforms that may help to address concerns about the fiduciary theory's potential for abuse.

Of course, these proposals for narrowing the accountability gap are premised upon the idea that the Security Council itself can become a credible fiduciary for humanity, and not merely a forum for Machiavellian political maneuvering among the world's most powerful states. Given the Security Council's mixed track record, there are valid grounds for skepticism about whether the Security Council is up to the task. ${ }^{124}$ Yet the Security Council need not be directed by angels to serve as an effective oversight body for humanitarian intervention. The deep political divisions and mutual distrust that attend Security Council decision-making may actually be a virtue if they can be channeled productively to generate rigorous review of humanitarian interventions. Developing effective mechanisms for post-authorization review could also make some P5 states

124 To the extent that the fiduciary theory depends on a well-functioning Security Council, this is a serious weakness, though it is one that the fiduciary theory shares with many other theories of humanitarian intervention, including those that treat humanitarian intervention as a form of supranational executive action. See, e.g., Bellamy, supra note 77, at 63 (observing that "both Francis Deng and Kofi Annan admitted that sovereignty as responsibility implied that sovereigns should be made accountable to a higher authority and that this required the creation of a legitimate and representative global body," but the Security Council "had to become more efficient, representative, and accountable in order to [serve this function]"). 
more willing to consider allowing humanitarian intervention in the future. Thus, even if international law cannot exclude political bias from coloring the Security Council's decision-making process, there may be ways to harness states' self-interest in the service of the fiduciary theory's emancipatory vision.

\section{Conclusion}

This Article has argued that legal scholars have been too quick to dismiss Grotius's contributions to the legal theory of humanitarian intervention. Updated for the twenty-first century, Grotius's characterization of humanitarian intervention as a fiduciary relationship best explains how foreign military intervention can facilitate human rights protection without unleashing new forms of international domination. When states intervene to protect foreign peoples from widespread and systematic abuse, they serve as fiduciaries, exercising foreign peoples' legal rights to self-defense on their behalf. By framing humanitarian intervention within a relational legal framework, the fiduciary theory ensures that international law regulates not only when states may use force abroad to protect human rights, but also how they must do so. Specifically, the fiduciary theory suggests that intervening states bear duties of loyalty and care, which require them to use their entrusted powers for the benefit of an oppressed people, including by respecting and protecting human rights such as the right to life. The fiduciary theory also reconciles foreign intervention with the principle of self-determination by requiring intervening states to consult with and honor the preferences of the people on whose behalf they purport to act. In these and other respects, the fiduciary theory's relational conception of humanitarian intervention clarifies the source and character of intervening states' authority to protect human rights abroad. To make the fiduciary theory of humanitarian intervention fully operative in practice, however, the international community must develop more robust institutions and procedures for holding intervening states accountable for the manner in which they exercise their entrusted powers. 
Theoretical Inquiries in Law 16.2 (2015) 